\title{
Study of Sintering Parameters and Sintering Additives Effect on selected properties of Silicon Nitride
}

Zuzana Gábrišová, Alena Brusilová, Pavol Švec

Institute of technologies and materials, Faculty of Mechanical Engineering, STU Bratislava, Pionierska 15, 82131 Bratislava. Slovak Republic. e-mail address: zuzana.gabrisova@stuba.sk

The subject of this article is the study of influence of sintering time and sintering additives on mechanical properties and wear resistance. $\mathrm{Si}_{3} \mathrm{~N}_{4}$ with $\mathrm{Al}_{2} \mathrm{O}_{3}+\mathrm{Y}_{2} \mathrm{O}_{3}$ additives (YAG) and $\mathrm{Si}_{3} \mathrm{~N}_{4}$ with $\mathrm{MgO}$ additives was used as an experimental materials. Compositions sintered for $30 \mathrm{~min}$ achieved optimal combination the hardness and fracture toughness - 15.05 GPa and 6.87 MPa.m ${ }^{1 / 2}$ for $\mathrm{Si}_{3} \mathrm{~N}_{4}-\mathrm{MgO}$ and 14.65 GPa and 5.71 MPa.m $\mathrm{Mor}^{1 / 2} \mathrm{Si}_{3} \mathrm{~N}_{4}-\mathrm{YAG}_{\text {. Wear }}$ was mostly influenced by the hardness of ceramic materials. The specimen with the highest hardness achieved the highest wear resistance. Wear resistance of ceramics decreased with the grain growth and with the transformation progress of narrow $\alpha-\mathrm{Si}_{3} \mathrm{~N}_{4}$ phase to prismatic $\beta-\mathrm{Si}_{3} \mathrm{~N}_{4}$ phase. The wear resistance of the studied ceramics can be described by model $\mathrm{V} \sim \mathrm{HV}^{-1}$. $\mathrm{Si}_{3} \mathrm{~N}_{4}-\mathrm{YAG}$ in comparison to $\mathrm{Si}_{3} \mathrm{~N}_{4}-\mathrm{MgO}$ has several times greater wear resistance.

Keywords: silicon nitride, sintering additives, mechanical properties, wear resistance

\section{Introduction}

An important position of silicon nitride in the industry is given by its properties, especially by its hardness and wear resistance, room and high-temperature strength (up to $1400^{\circ} \mathrm{C}$ ) and by its resistance to corrosion and creep $[1,2]$. Mechanical properties and oxidation resistance of $\mathrm{Si}_{3} \mathrm{~N}_{4}$ depend to a great extent on the character and from the quantity of the secondary phase, i.e on the sintering additives of the material $[3,4,5]$. The maximum application temperature, for example, is $1350^{\circ} \mathrm{C}$ in the case of sintering additives $\mathrm{Al}_{2} \mathrm{O}_{3}+\mathrm{Y}_{2} \mathrm{O}_{3}$, whereas it is only $1000^{\circ} \mathrm{C}$ in the case of $\mathrm{MgO}$. However, the most important disadvantage of the ceramics is brittleness. It is well known, that due to the bad compactibility of silicon nitride, oxide additives are used. Thus, such oxide additives as $\mathrm{MgO}, \mathrm{Al}_{2} \mathrm{O}_{3}$ and $\mathrm{Y}_{2} \mathrm{O}_{3}$ are most commonly used for formation of such phases, as $\mathrm{SiAlON}, \mathrm{MgSiO}_{4}$ and $\mathrm{MgSiO}_{3}$ [6].

$\mathrm{Si}_{3} \mathrm{~N}_{4}$ has been successfully used in a wide variety of engineering applications involving contact with metallic surfaces such as drawing dies, roller bearings, cutting tools, and automotive or aerospace engine parts $[7,8]$. Abrasive wear is the most common mechanism of ceramic material removal. Two basic mechanisms of surface damage are applied during the abrasive wear of ceramics: microcutting and microcracking [8-10].

The mechanisms of microcutting can be described according to a model that comes from Rabinowitz's conception of abrasive wear mechanism description [11]. In this model the abrasive particle in the cone shape makes grooves on the surface of the solid body. The removed material volume $\mathrm{V}$ can be described by equation (1):

$$
V=\frac{F \cdot l}{\pi \cdot \operatorname{tg} \alpha \cdot H V},
$$

where $\mathrm{F}$ is the force necessary to get the abrasive particle into the abraded material, 1 is the length of a groove on the surface if the cone moves during relative motion in parallel with the worn material surface, HV is the hardness of ceramics, and $\alpha$ is the angle of the cone which participates in the grooving of the surface. It follows from equation (1) that the removed material volume is dependent only on one material property, hardness HV.

If we consider the mechanism of microcracking, the abrasive particle creates a crack in the plane of the load axis after the overrun of the specific limit value of the load. Cracks spread to the sample surface, where they can develop into a fracture $[9,12]$. The volume of wear $\mathrm{V}$ can be expressed by means of equation (2).

$$
V=\frac{F^{9 / 8}}{K_{I C}^{1 / 2} \cdot H V^{4 / 5}} \cdot\left(\frac{E}{H V}\right)^{4 / 5} . l,
$$

In this equation (2) 1 is length of path of abrasive particle, $\mathrm{F}$ is load on the abrasive particle, $\mathrm{K}_{\mathrm{IC}}$ is fracture toughness of the ceramics, $\mathrm{HV}$ is the hardness of the ceramics and $\mathrm{E}$ is the modulus of elasticity of the worn ceramic material. According to equation (2) the removed material, volume $\mathrm{V}$, is dependent on three material properties: the modulus of elasticity $\mathrm{E}$, the fracture toughness $\mathrm{K}_{\mathrm{IC}}$ and hardness $\mathrm{HV}$.

According to some works $[11,13]$ the ratio of $\mathrm{K}_{\mathrm{IC}} / \mathrm{HV}$ values appears as the main characteristic determining dominant wear mechanisms of brittle materials during abrasive wear. This parameter defines the dominant wear mechanism at the point of contact. The mechanism of microcutting is dominant at a high value of this rate and simultaneously at a high value of fracture toughness, i.e. wear volume will be depended on hardness (V 1/HV). Brittle fractures dominant at a low value of the rate $\mathrm{K}_{\mathrm{IC}} / \mathrm{HV}$, i.e. wear will increase with decreasing fracture toughness ( $\sim \sim \mathrm{K}_{\mathrm{IC}} / \mathrm{HV}$ ). This influences the growth of wear intensity. According to equations (1) the intensity of microcutting decreases with the hardness of ceramics, and according to equation (2) the intensity of microcracking decreases with fracture toughness of the worn surface. This can lead to a transition from plastic microcutting to brittle microcracking during abrasive wear [8]. Besides the mechanical properties of ceramics, the character of the structure like grain size and $\beta$-Si3N4 phase ratio plays an important role in determining how the ceramics will react 
to specific states of stress which arise under specific conditions of wear $[9,14]$.

\section{Experiment}

The experimental materials was prepared by hot pressing in nitrogen atmosphere. The hot pressing of the experimental materials was performed on a laboratory hot press with a special construction of heating body [15], under the following conditions: the temperature $1680^{\circ} \mathrm{C}$, the pressure $34 \mathrm{MPa}$.

For the study were choosen two chemical composition of ceramic samples $\mathrm{Si}_{3} \mathrm{~N}_{4}-10 \% \mathrm{YAG}$ and $\mathrm{Si}_{3} \mathrm{~N}_{4}$ $5 \% \mathrm{MgO}$. Three various sintering time 5, 30 and $40 \mathrm{~min}$ were applied. In view of the fact that $\mathrm{Si}_{3} \mathrm{~N}_{4}$ ceramics has extremely low diffusional coefficient which is caused by a strong covalent bond between $\mathrm{Si}$ - and $\mathrm{N}$ - atoms and low temperature of $\mathrm{Si}_{3} \mathrm{~N}_{4}$ decomposition at normal pressure, it isn't possible to reach $\mathrm{Si}_{3} \mathrm{~N}_{4}$-fulldense material only by sintering in solid phase $[16,17]$. It is necessary a presence of sintering additives to acquisition of a fulldense material. During a sintering these additives react to $\mathrm{SiO}_{2}$ and they creat a crystalline phases to each other, which support a sintering process [18]. The sintering additives $\mathrm{Y}_{2} \mathrm{O}_{3}$ and $\mathrm{Al}_{2} \mathrm{O}_{3}$ were added to prime $\mathrm{Si}_{3} \mathrm{~N}_{4}$ powder because of creating yttrium aluminium garnet $\mathrm{Y}_{3} \mathrm{Al}_{5} \mathrm{O}_{12}$ (YAG). This phase contributes to the sintering ability of $\mathrm{Si}_{3} \mathrm{~N}_{4}$ ceramics.

In this article the influence of pressing time on the structure, density and selected mechanical properties (hardness, fracture toughness and wear resistance) was studied.

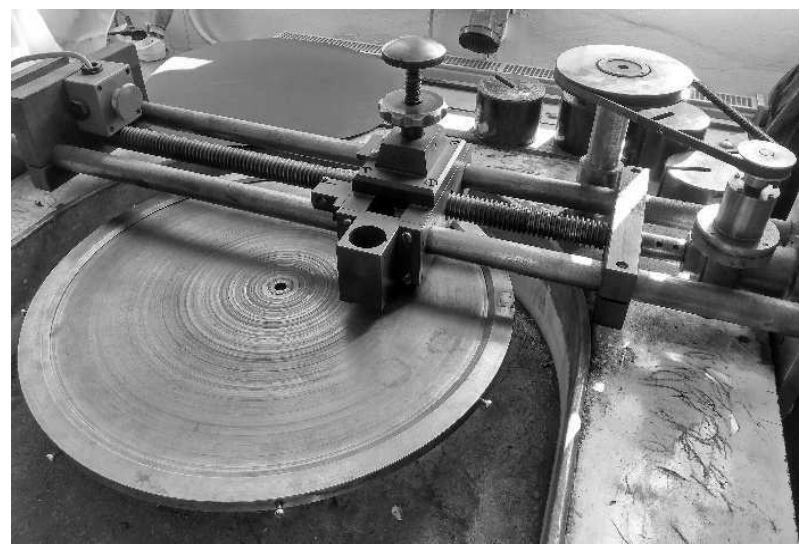

Fig. 1 The test equipment

Densities of the hot pressed ceramics were measured by the Archimedes's method. Hardness and fracture toughness were determined by means of the Vickers indentation method. The wear resistance was evaluated by means of grinding the sample using a pin on disk method [19]. Test samples with diameters of $8.4 \mathrm{~mm}$ and a height of $10 \mathrm{~mm}$ were placed in contact with corundum grinding paper with a graininess of $120 \mu \mathrm{m}$. The grinding trajectory was $125 \mathrm{~m}$ and the pressure was $1.5 \mathrm{MPa}$. Sliding speed max. $0.5 \mathrm{~m} . \mathrm{s}^{-1}$, radial movement $1.5 \mathrm{~mm} / \mathrm{ot}$, dry friction. For experiments was used the equipment for abrasive wear testing (Fig. 1). The wear resistance was determined based on the volume loss of the samples relative to the grinding trajectory according to equation (3):

$$
V_{V / s}=\frac{\Delta m}{\rho \cdot l},
$$

where $\mathrm{V}_{\mathrm{V} / \mathrm{s}}$ is volume loss of the samples, $\Delta m$ is weight loss of the samples, $\rho$ is density of the sample and 1 is grinding path of the sample. The wear resistance was determined based on the volume loss of the samples relative to the grinding trajectory. The microstructures of the hot pressed ceramics were observed using a scanning electron microscope JEOL IT- 300-LV.

\section{Results and discussion}
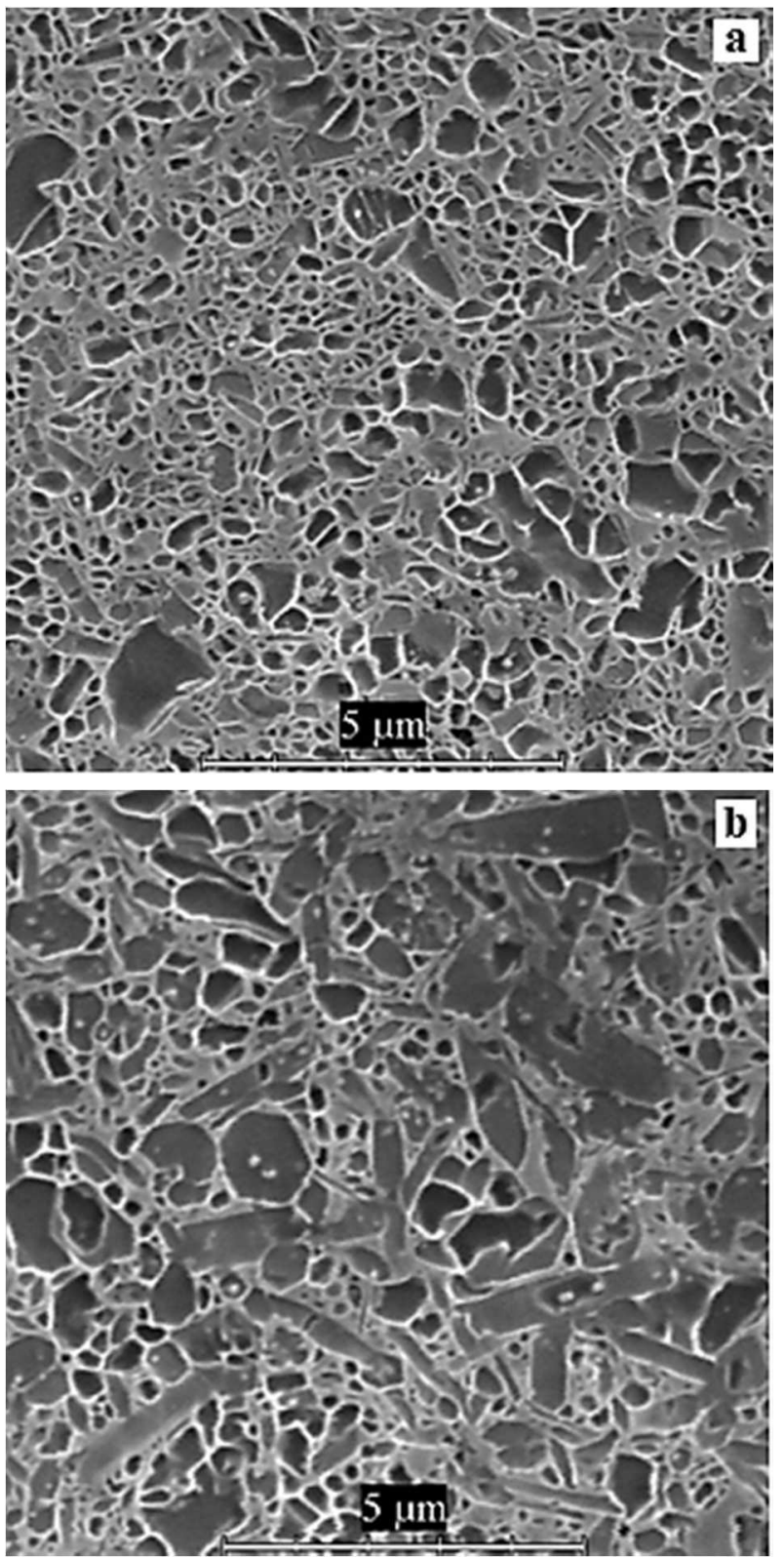

Fig. 2 Microstructure of Si3N4 ceramics with 10 wt.\% $Y A G$ sintered a) $5 \mathrm{~min}$, b) $30 \mathrm{~min}$

Fig.2 represents the microstructure of $\mathrm{Si}_{3} \mathrm{~N}_{4}-\mathrm{YAG}$ sintered for 5 and $30 \mathrm{~min}$. The microstructure $\mathrm{Si}_{3} \mathrm{~N}_{4}-$ YAG contains equiaxed matrix $\alpha-\mathrm{Si}_{3} \mathrm{~N}_{4}$ grains and large elongated $\beta-\mathrm{Si}_{3} \mathrm{~N}_{4}$ grains too. Along the boundary $\mathrm{Si}_{3} \mathrm{~N}_{4}$ phase is created crystalline phase $\mathrm{Y}_{3} \mathrm{Al}_{5} \mathrm{O}_{12} / \mathrm{YAG} /$ which 
is brittle. In this figure it is possible to see the microstructure sintered for 5 min (Fig.2a) with small grains and the microstructure after the sintering time prolonged over $30 \mathrm{~min}$ (Fig.2b) which contains large grains of $\beta-\mathrm{Si}_{3} \mathrm{~N}_{4}$. These microstructures represent growth of crystals during sintering - the large grains developed with increased sintering time.

In the Fig. 3 the microstructure of $\mathrm{Si}_{3} \mathrm{~N}_{4}-\mathrm{MgO}$ sintered for 5 and $30 \mathrm{~min}$ is represented. Alike as the microstructure $\mathrm{Si}_{3} \mathrm{~N}_{4}-\mathrm{YAG}$, the microstructure $\mathrm{Si}_{3} \mathrm{~N}_{4}-$ $\mathrm{MgO}$ is created with equiaxed matrix $\alpha-\mathrm{Si}_{3} \mathrm{~N}_{4}$ grains and large elongated $\beta-\mathrm{Si}_{3} \mathrm{~N}_{4}$ grains. There is the glass secondary $\mathrm{MgSiO}_{3}$ phase along the boundary $\mathrm{Si}_{3} \mathrm{~N}_{4}$ phase. The glass phase was created during a sintering in presence of liquid phase by the reaction $\mathrm{MgO}$ with free $\mathrm{Si}$ at the temperature $\sim 1450^{\circ} \mathrm{C}[20]$. The large grains developed with increased sintering time.
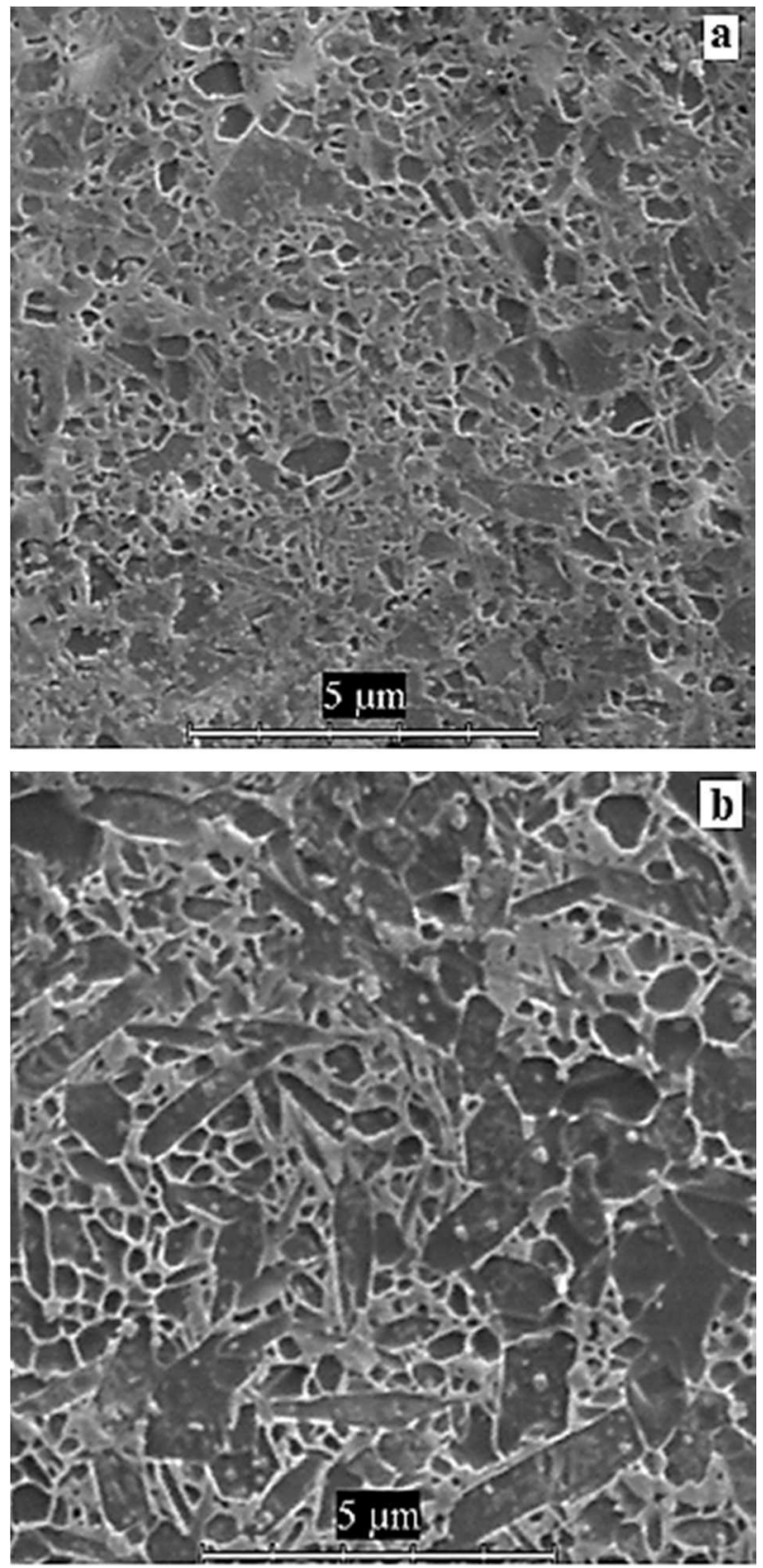

Fig. 3 Microstructure of Si3N4 ceramics with 5 wt.\% $\mathrm{MgO}$ sintered a) $5 \mathrm{~min}$, b) $30 \mathrm{~min}$
In the Fig. 4 is showed the relative density of $\mathrm{Si}_{3} \mathrm{~N}_{4}-$ $\mathrm{MgO}$ and $\mathrm{Si}_{3} \mathrm{~N}_{4}-\mathrm{YAG}$ ceramics as a function of sintering time for 5, 30 and $40 \mathrm{~min}$. In $\mathrm{Si}_{3} \mathrm{~N}_{4}-\mathrm{MgO}$ ceramics samples, the values of relative density declined slightly from $97.85 \%$ to $97.46 \%$ of theoretical density.

For composition with YAG, the values of relative density was in range from $96.02 \%$ to $98.5 \%$ of theoretical density till $30 \mathrm{~min}$. The prolongation of sintering time (till $30 \mathrm{~min}$ ) had possitive effect on the density. However, the density had a tendency to decrease as the sintering time prolonged over $30 \mathrm{~min}$. It could be caused by complete phase transformation to $30 \mathrm{~min}$.

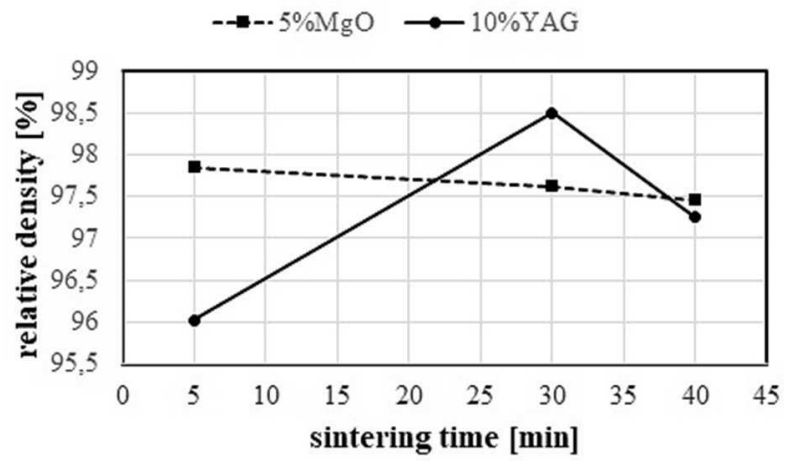

Fig. 4 Dependence of relative density on the time of pressing

Fig.5 represents the effect of sintering time on the hardness of $\mathrm{Si}_{3} \mathrm{~N}_{4}$ ceramics - the hardness for both materials decreased with prolongation of sintering time. In the study [21] was investigated the effect $\% \beta$ content on the hardness and fracture of $\mathrm{Si}_{3} \mathrm{~N}_{4}-\mathrm{YAG}$ system. There was found decreasing of hardness with increasing $\beta-\mathrm{Si}_{3} \mathrm{~N}_{4}$ content. It is known, during sintering $\alpha$ - to $\beta$-phase transformation develop with the rodlike $\beta-\mathrm{Si}_{3} \mathrm{~N}_{4}$ grain formation and growth. The $\beta-\mathrm{Si}_{3} \mathrm{~N}_{4}$ grains give the poorer values of hardness than the equiaxed $\alpha-\mathrm{Si}_{3} \mathrm{~N}_{4}$ grains [22]. This confirms the relationship between the hardness and microstructure depending on prolongation of sintering time.

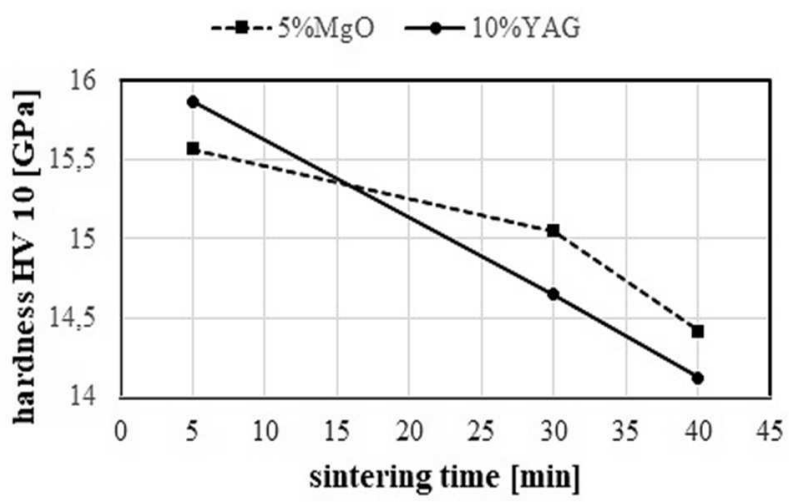

Fig. 5 Dependence of hardness on the time of pressing

Registered indentation cracks in $\mathrm{Si}_{3} \mathrm{~N}_{4}$ with $\mathrm{MgO}$ additive were of Palmqvist's type, unlike those in $\mathrm{Si}_{3} \mathrm{~N}_{4}$ with $\mathrm{Al}_{2} \mathrm{O}_{3}+\mathrm{Y}_{2} \mathrm{O}_{3}$ additives, which are of half-penny shape. Palmqvist's type is characteristic for tougher ceramic materials. Fig.6 indicates the relationship between fracture 
toughness and pressing time. For both materials to 30 minutes the fracture toughness was increasing. In samples $\mathrm{Si}_{3} \mathrm{~N}_{4}$ with $\mathrm{MgO}$ after achieving of maximum values (at $30 \mathrm{~min}) \mathrm{K}_{\mathrm{IC}}$ began to decrease. Prolongation of sintering time (to $40 \mathrm{~min}$ ) in samples with YAG values $\mathrm{K}_{\mathrm{IC}}$ increased slightly. It has been reported that the hardness of $\alpha-\mathrm{Si}_{3} \mathrm{~N}_{4}$ single crystals was higher than that $\beta$-single crystals. The large elongated grains with high aspect ratio deflect the propagation of cracks, thus increasing the fracture toughness of ceramics.

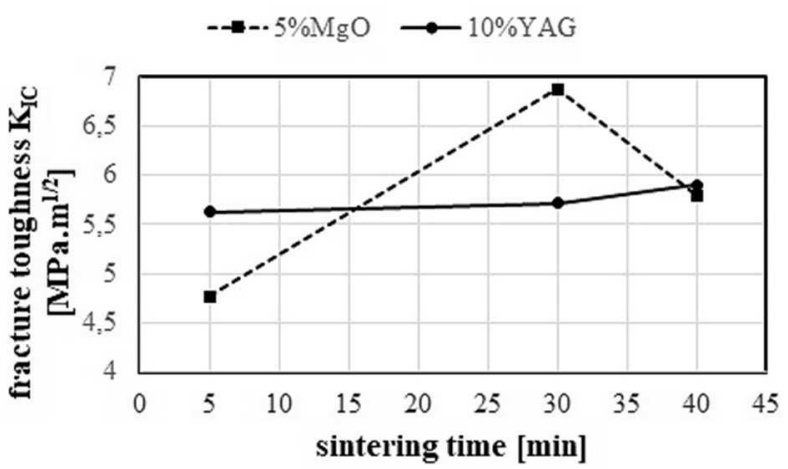

Fig. 6 Dependence of fracture toughness on on the time of pressing

The values of $\mathrm{K}_{\mathrm{IC}}$ increased with increasing of elongated $\beta-\mathrm{Si}_{3} \mathrm{~N}_{4}$ grains volume content. However, it was expected that fracture toughness will eventually be limited by other factors. The abnormal grain growth of $\beta-\mathrm{Si}_{3} \mathrm{~N}_{4}$ decreased the fracture toughness because very large grains affect as the origin crack propagation. Also, with $\beta$ $\mathrm{Si}_{3} \mathrm{~N}_{4}$ content increase from 0 to $65 \%$, the fracture toughness increased too. After saturation up to $65 \%$ of $\beta$ content, the $\mathrm{K}_{\mathrm{IC}}$ values began to decrease [23].

The effect of the additional concentration and sintering time on the wear of ceramic samples can be seen in Fig. 7. From this figure it can be seen that the volume change during the wear test decreased with the increasing of the additions and with sintering time. The highest wear resistance was achieved in the $10 \%$ YAG sample, which was pressed for only $5 \mathrm{~min}$, and the least wear resistance was with the $5 \% \mathrm{MgO}$ pressed for the longest time of 40 $\min$.

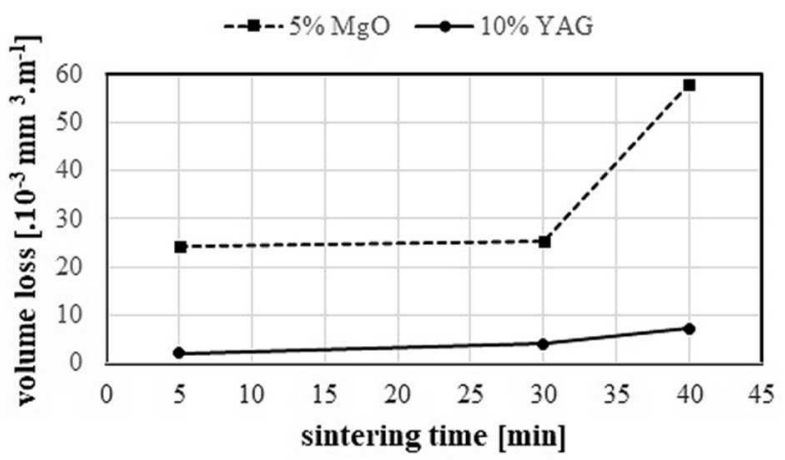

Fig. 7 Dependence of volume loss on the time of pressing

The effects of the measured mechanical properties on the wear properties of the ceramic samples were studied in detail and are presented in the Fig. 8, 9 and 10.
Hardness had a positive effect on wear resistance for both materials (Fig. 8). Higher hardness resulted in less wear. As the highest hardness was measured in the ceramics with $10 \%$ YAG that was pressed for $5 \mathrm{~min}$. These samples had the smallest volume losses. The highest volume losses were measured in the $5 \% \mathrm{MgO}$ samples pressed for $40 \mathrm{~min}$. These samples had the smalles hardness. The results in Fig. X correspond well with model (V $\mathrm{HV}^{-1}$ ), where the volume losses $\mathrm{V}$ during the wear tests vary inversely in proportion to the hardness $\mathrm{HV}$ of the ceramics.

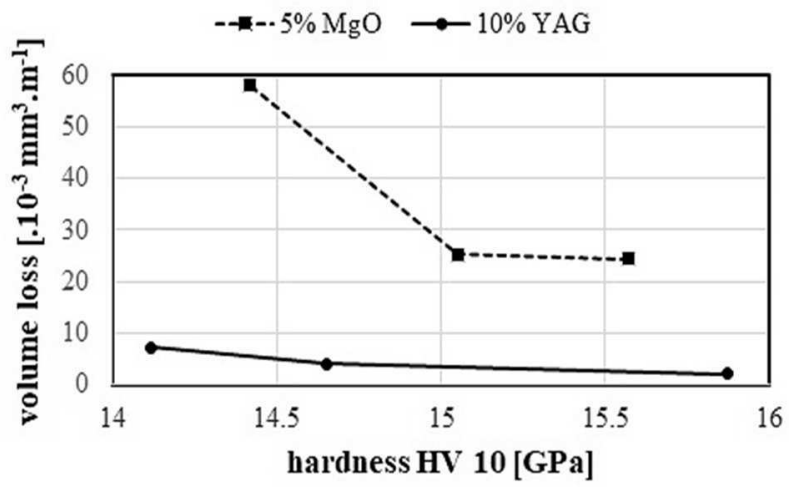

Fig. 8 Dependence of volume loss on hardness

A very interesting development was noted when the effect of fracture toughness on wear was measured (Fig. 9). Compositions showed the different progress.

The wear volume was increasing with incresing fracture toughness in the system $\mathrm{Si}_{3} \mathrm{~N}_{4}-\mathrm{MgO}$. After maximal wear value achieving $\left(58.03 .10^{-3} \mathrm{~mm}^{3} . \mathrm{m}^{-1}\right.$ at pressing time $40 \mathrm{~min}$.), the wear value decreased. In the system $\mathrm{Si}_{3} \mathrm{~N}_{4}-\mathrm{YAG}$, the wear volume was increasing along with increasing fracture toughness. The maximal wear value $\left(7.19 .10^{-3} \mathrm{~mm}^{3} \cdot \mathrm{m}^{-1}\right)$ has been achieved at the pressing time $40 \mathrm{~min}$.

For both materials, the lowest wear value has been measured at the lowest fracture toughness value corresponding to the pressing time $5 \mathrm{~min}$. The effect of fracture toughness on wear resistance was less marked. The effect of grain size and chemical composition was dominant. The excessive grains growth decreases the fracture toughness what can activate intensive microcracking [22]. The picture $\mathrm{Y}$ shows that the system $\mathrm{Si}_{3} \mathrm{~N}_{4}-\mathrm{MgO}$ proves several times lower wear resistance as the system $\mathrm{Si}_{3} \mathrm{~N}_{4}-$ YAG.

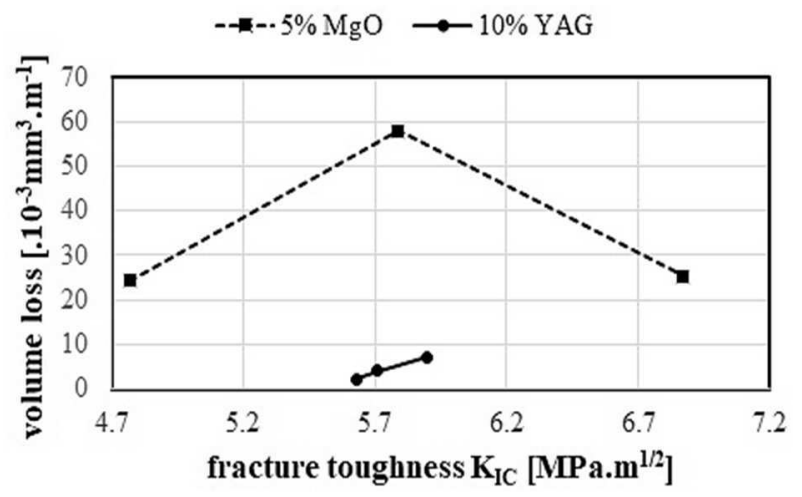

Fig.9 Dependence of volume loss on fracture toughness 
Wear behavior may be better described by the model which reflects the effect of ratio fracture toughness / hardness on wear rate. This can be seen in Fig. 10. These relations fit very well for each separate composition. The higher the value of the calculated ratio of fracture toughness to hardness is, the higher the wear rate is for both compositions. The highest wear rate was noticed in the 5 $\% \mathrm{MgO}$ specimen that was pressed for $40 \mathrm{~min}$. In the specimens with $10 \%$ YAG pressed 40 min was noticed too the highest wear rate. The ratio of fracture toughness to hardness accurately describes the relationship between the decrease of wear resistance in spite of the transformation progress $\alpha-\mathrm{Si}_{3} \mathrm{~N}_{4}$ phase to the $\beta-\mathrm{Si}_{3} \mathrm{~N}_{4}$ phase, and the increase in the rate of wear in spite of grain growth.

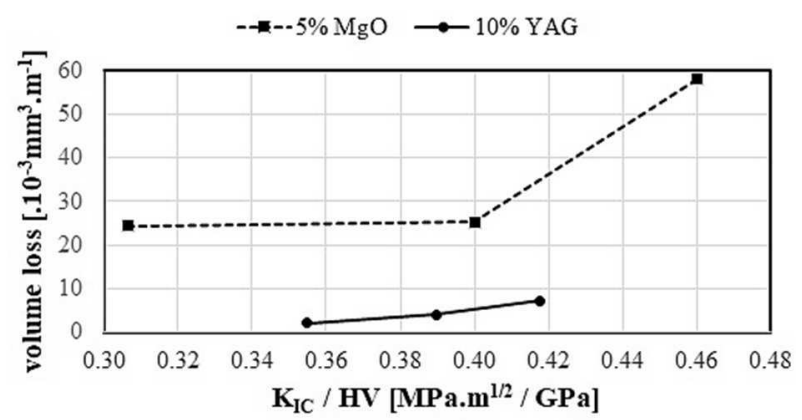

Fig. 10 Effect of ratio KIC / HV of volume loss

\section{Conclusions}

In this paper was evaluated the effect of preparation parameters chosen, such as chemical composition, sintering conditions in the microstructure, mechanical properties and wear resistance.

The achieved results can be summarized as follows:

- The microstructure $\mathrm{Si}_{3} \mathrm{~N}_{4}-\mathrm{YAG}$ and $\mathrm{Si}_{3} \mathrm{~N}_{4}-$ $\mathrm{MgO}$ contains equiaxed matrix $\alpha-\mathrm{Si}_{3} \mathrm{~N}_{4}$ grains and large elongated $\beta-\mathrm{Si}_{3} \mathrm{~N}_{4}$ grains too. The large grains developed with increased sintering time.

- Compositions sintered for $30 \mathrm{~min}$ achieved optimal combination the hardness and fracture toughness - 15.05 GPa and 6.87 MPa.m ${ }^{1 / 2}$ for $\mathrm{Si}_{3} \mathrm{~N}_{4}$ $-\mathrm{MgO}$ and 14.65 GPa and 5.71 MPa.m ${ }^{1 / 2}$ for $\mathrm{Si}_{3} \mathrm{~N}_{4}-\mathrm{YAG}$.

- Sintering additives $\mathrm{Al}_{2} \mathrm{O}_{3}+\mathrm{Y}_{2} \mathrm{O}_{3}$ and $\mathrm{MgO}$ have influence on the type of crack indentation with Vickers indenter. Indentation cracks in $\mathrm{Si}_{3} \mathrm{~N}_{4}$ with $\mathrm{MgO}$ additive are of Palmqvist's type, unlike those in $\mathrm{Si}_{3} \mathrm{~N}_{4}$ with $\mathrm{Al}_{2} \mathrm{O}_{3}+\mathrm{Y}_{2} \mathrm{O}_{3}$ additives, which are of half-penny shape.

- Wear was mostly influenced by the hardness of ceramic materials. The specimen with the highest hardness achieved the highest wear resistance. Wear resistance of ceramics decreased with the grain growth and with the transforma- tion progress of narrow $\alpha-\mathrm{Si}_{3} \mathrm{~N}_{4}$ phase to prismatic $\beta-\mathrm{Si}_{3} \mathrm{~N}_{4}$ phase. The wear resistance of the studied ceramics can be described by model $\mathrm{V} \sim$ $\mathrm{HV}^{-1}$.

- $\mathrm{Si}_{3} \mathrm{~N}_{4}-\mathrm{YAG}$ in comparison to $\mathrm{Si}_{3} \mathrm{~N}_{4}-\mathrm{MgO}$ has several times greater wear resistance.

\section{Acknowledgement}

The results given in this paper were obtained as part of VEGA 1/0298/18 research project. Support of the UVP STU Bratislava ITMS 26240220084 project is also acknowledged.

\section{References}

[1] PÁNEK, Z., FIGUSCH, V., HAVIAR, M., LIČKO, T., ŠAJGALÍK, P., DUSZA, J. (1992). Konštrukčná keramika. Bratislava: R\&D. ISBN 80-85488-00-0

[2] HVIZDOŠ, P., KAŠIAROVÁ, M., HNATKO, M., ŠAJGALÍK, P. (2004). In: Kovové Mater., 42, p. 51

[3] KOVALČÍK, J., HVIZDOŠ, P., DUSZA, J., ŠAJGALÍK, P., HNATKO, M., REECE, M. (2003). In: Kovové Mater., 41, p. 377

[4] HAN, W., Li, Y., CHEN, G., YANG, Q. (2017). Effect of sintering additive composition on microstructure and mechanical properties of silicon nitride. In: Materials Science and Engineering: $A, 700,2017$, p. 17

[5] BRUSILOVÁ, A., GÁBRIŠOVÁ, Z. (2014). Vplyv parametrov spekania na oteruvzdornost' Si3N4. In: Strojírenská technologie. Roč. 19, č. 3, s. 149 ISSN 1211-4162.

[6] SIROTA, V., LUKIANOVA, O., KRASILNIKOV, V., SELEMENEV, V., DOKALOV, V. (2016). Microstructural and physical properties of magnesium oxide-doped silicon nitride ceramics. In: Results in Physics, 6, p. 82

[7] BRUSILOVÁ, A., GÁBRIŠOVÁ, Z., IŽDINSKÁ, Z. (2013). Progresívne materiály v oblasti ložísk. In: Strojírenská technologie, 18, č. 1, s. 10. ISSN 1211-4162.

[8] KHADER, I., RENZ, A., KAILER, A. (2017). A wear model for silicon nitride in dry sliding contact against a nickel-base alloy. In: Wear, 2017, Vol. 376-377, part A, p. 352

[9] BOCANEGRA-BERNAL, M. H., MATOVIC, B. (2009). Dense and near-net shape fabrication of Si3N4 ceramics. In: Mat. Sci. Eng. A, 500, p. 130

[10] DOGAN, C. P., HAWK, J. A. (2001). Microstructure and abrasive wear in silicon nitride ceramics. In: Wear, 250, p. 256 
[11] RABINOWICZ, E. (1995). Friction and wear of materials 2 th ed. New York : John Wiley and Sons

[12] HSU, S. M., SHEN, M. (2004). Wear of ceramics. In: Wear, 256, p. 867

[13] WILLIAMS, J. A. (2005). Wear and wear particles - some fundamentals. In: Tribology International, 38, p. 863

[14] LEE, B. T., HAN, B. D., KIM, H. D. (2003). Comparison of fracture characteristic of silicon nitride ceramics with and without second crystalline phase. In: Materials Letters, 58, p. 74

[15] PULC, V., GONDÁR, E., ŠVEC, P. (1992). Zbornik z medzinárodnej konferencie pri príležitosti 40.výročia založenia Strojníckej fakulty TU v Košiciach. Košice: TU Košice

[16] YANG, J. F., OHJI, T. (2000). In: J. Amer. Soc., 83, p. 2094

[17] BELLOSI, A., BABINI, G. N. (1999). In: Key Engineer. Materials, 161, p. 203
[18] ZHANG, Y. H., EDWARDS, L. (1998). In: $J$. Amer. Ceram. Soc., 81, p. 1861

[19] VAN DOANL, T., KUSMIČL, D., POSPÍCHAL, M., TRAN, Q. D., NGUYEN, V. T. (2017). Friction and Wear Behaviour of 42CrMo4 Steel Treated by Tenifer, Hard Chrome and Plasma Nitriding Technologies.In: Manufacturing Techno$\log y, 17$, č. 2, p. 217. ISSN 1213-2489

[20] EVANS, A. G., MARSHAL, D. B. (1981). ASM Metal park, Ohio, p. 439

[21] KAWAOKA, H., CHOA, Y. H., NIIHARA, K. (1999). In: Key Eng. Mater., 162, p. 225

[22] NAKAMURA, M., HIRAO, K. (2003). In: Wear, 254, p. 94

[23] ŠVEC, P., BRUSILOVÁ, A. (2011). Tribologické vlastnosti nitride kremika. Bratislava: Nakladatel'stvo STU. ISBN 987-80-227-3459-2 